\title{
Z badań Ananiasza Zajączkowskiego nad folklorem karaimskim
}

\author{
Piotr Muchowski \\ Uniwersytet im. Adama Mickiewicza w Poznaniu \\ Wydział Neofilologii

\begin{abstract}
Professor Ananiasz Zajączkowski's Research
\end{abstract} \\ on the Folklore of the Polish-Lithuanian Karaites
}

\begin{abstract}
Summary: This article deals with Professor Ananiasz Zajączkowski's work on the folklore of the Polish-Lithuanian Karaites before the First World War. Ananiasz Zajączkowski authored several articles in which he edited and/or described manuscripts in the Karaite language. These manuscripts, which included works on fortune-telling, magic and herbalism, originated in late $19^{\text {th }}$-century Lithuania. The article describes the genesis of works on Karaite folklore and challenges Ananiasz Zajączkowski's thesis regarding the origins of the Turkic peoples. It quotes a number of Hebrew manuscripts kept in Karaite collections and proves that most of the works have been translated into the Karaite language.
\end{abstract}

Keywords: Ananiasz Zajączkowski, Karaite folklore, literature of the Polish-Lithuanian Karaites

Do bogatego dorobku naukowego profesora Ananiasza Zajączkowskiego należy kilka prac z zakresu badań nad folklorem Karaimów w Europie Wschodniej. Prace te, mimo że w większości opublikowane zostały w okresie międzywojnia, są do dziś cytowane i wskazywane jako jedno z ważnych 
i autorytatywnych źródeł wiedzy o folklorze i kulturze ludowej Karaimów polsko-litewskich ${ }^{1}$.

Są to przede wszystkim trzy artykuły opublikowane przez Ananiasza Zajączkowskiego w „Myśli Karaimskiej” w latach dwudziestych i trzydziestych², ale także kilka mniejszych tekstów o charakterze przyczynkarskim w innych publikacjach ${ }^{3}$.

W artykułach tych Ananiasz Zajączkowski wydał lub opisał pewną liczbę utworów w języku karaimskim (turkijskim), które - jak podaje - należały do literatury ludowej Karaimów polsko-litewskich. Utwory te zaświadczone zostały w rękopisach z drugiej połowy dziewiętnastego wieku. Większość z nich pochodziła z Poniewieża. Są to:

1. „Wróżby z drgań części ciała”,

2. „Wykładanie snów”, czyli sennik przypisywany prorokowi Danielowi

3. „Księga Losów”, czyli „Goralot Achitofela z Gilo”,

1 Por. np. A. Sulimowicz, Prace prof. A. Zajaczkowskiego poświęcone historii i kulturze Karaimów, [w:] H. Kobeckaitė, T. Bairašauskaitė (red.). Kipčiaku tiurku Orientas Lietuvoje: istorija ir tyrimu perspektyva: tarptautines mokslines konferencijos, skirtos profesoriaus dr. Ananiaszo Zajaczkowskio 9o-sioms gimimo metinèms, medžiaga, Vilnius, 1993 m. spalio 14-15 d., Vilnius 1994, s. 44; M. Kizilov, The Karaites of Galicia. An Ethnoreligious Minority among the Ashkenazim, the Turks, and the Slavs, 1772-1945. Leiden, Boston 2009, s. 173.

2 Wróżby z drgania części ciała (sekirme jorałary), „Myśl Karaimska”, t. 2 z.1 (1929), s. 23-31; $Z$ dziejów literatury wróżbiarskiej. (I. „Objaśnienia drgañ” części ciała, II. „Księga losów”), „Myśl Karaimska” z. 11 (1935-1936), s. 24-39; Teksty i studia folklorystyczne. I. Wykładanie snów. II. Lecznictwo ludowe, [w:] Ksiega pamiątkowa ku czci J. E. Hachana H. S. Szapszała w X-ta rocznice Jego Ingresu, „Myśl Karaimska”, z. 12 (1938), s. 41-59.

3 Por. Karaimi na Wolyniu. Osobne odbicie z „Rocznika Wołyńskiego” tom III, Równe 1933 (Nakładem Zarządu Wołyńskiego Okręgu Związku Nauczycielstwa Polskiego), s. 9-13; Tatarsko-karaimskie piosenki ludowe z Krymu (t. zw. čyy), „Rocznik Orientalistyczny”, t. 14 (1938), s. 38-65; Karaims in Poland: History, Language, Folklore, Science, La Haye-Paris 1961, s. 60-63.

4 Por. A. Zajączkowski, Wróżby z drgania czéści ciała (sekirme jorałary), „Myśl Karaimska”, t. 2, z. 1 (1929), s. 23-31.

5 Por. A. Zajączkowski, Teksty i studia..., „Myśl Karaimska”, z. 12 (1938), s. 41-50.

6 Por. A. Zajączkowski, Z dziejów literatury wróżbiarskiej, „Myśl Karaimska”, z. 11 (1935-1936), s. 36-39. 
4. Recepty zielarskie i formuły pseudo-medyczne (definiowane przez autora jako zamawianie choroby, odpędzanie choroby, tudzież praktyki o charakterze terapeutycznym i profilaktycznym) ${ }^{7}$,

5. Teksty w rodzaju hemerologion ${ }^{8}$.

Teksty „Wróżb z drgań części ciała” i „Wykładania snów” zostały wydane krytyczne przez Zajączkowskiego w całości. Tekst karaimski został podany w transkrypcji z aparatem krytycznym i polskim przekładem ${ }^{9}$. Z innych tekstów przełożone zostały tylko fragmenty lub podane jedynie opisy. W przypadku „Księgi losów” autor zamieścił ogólne omówienie tekstu oraz cytaty pojedynczych ustępów w polskim przekładzie. Zapowiedział przy tym publikację całości tego tekstu, zapisanego „w języku zachodniokaraimskim, narzeczu trockim”, co jednak nie nastąpiło. W „Lecznictwie ludowym” wzmiankuje m.in. przepisy o charakterze magiczno-leczniczym zebrane na jego prośbę przez J. Maleckiego od starszych osób. Wspomina także rękopis w języku karaimskim z drugiej połowy XIX w., zawierający około 200 przepisów lekarskich (jako przykład podaje osiem takich recept $\left.{ }^{11}\right) \mathrm{i}$ innych (m.in. formuła zaklęcia na ujawnienie złodzieja). Inny odnotowany przez niego rękopis, z 1880 r., zawiera przepisy o charakterze zielarskim. Przytacza z niego przykładowe przepisy z wykorzystaniem szałwii, goryczki i kobylego szczawiu. Cytuje ustęp tekstu karaimskiego w transkrypcji i podaje polski przekład ${ }^{12}$. Wskazuje również szczegółowo dwa utwory typu hemerologion. Zawierają one listy dni odpowiednich do spożywania określonych pokarmów oraz dni odpowiednie do zabiegu flebotomii. Co warto zauważyć, Zajączkowski podawał, że są to tylko teksty przykładowe, zaś w znanych mu zbiorach rękopiśmiennych Karaimów polsko-litewskich znajduje się wiele podobnych tekstów.

Podkreślić należy także, że podstawą tych prac są rękopisy w języku karaimskim i są one zapisem żywej w początkach XX w. jeszcze kultury ludowej. Publikowane były, gdy język karaimski był powszechnie używany, stąd niewątpliwie są również ważnym pomnikiem języka karaimskiego (w publikacjach

7 Por. A. Zajączkowski, Teksty i studia..., „Myśl Karaimska”, z. 12 (1938), s. 50-58.

8 Por. tamże, s. 59.

9 Por. A. Zajączkowski, Wróżby z drgania..., s. 24-29; Teksty i studia..., „Myśl Karaimska”, z. 12 (1938), s. 44-49.

10 A. Zajączkowski, $Z$ dziejów literatury wróżbiarskiej, s. 37.

11 Por. A. Zajączkowski, Teksty i studia..., s. 53-55.

12 Por. tamże, s. 56-58. 
teksty są podawane w transkrypcji sporządzonej przez autora). Co istotne, folklor karaimski jest opisywany przez wykształconego członka społeczności, posiadającego regularne wykształcenie religijne i prowadzącego działalność naukową w zakresie turkologii, będącego nadto bliskim współpracownikiem Seraji Szapszała. Tym samym, są one, jak można sądzić, wyjątkowym i autorytatywnym zapisem ówczesnego folkloru karaimskiego. Ich wartość jest oczywiście tym większa, że takich publikacji jest niewiele, zaś potencjalnych informatorów, którzy mogliby wzbogacić naszą wiedzę o kulturze ludowej Karaimów sprzed międzywojnia chyba już nie ma.

Wskazując na wartość poznawczą tych prac i ich unikatowość, chciałbym w tym miejscu szerzej odnieść się do jednego ważnego aspektu badawczego tych publikacji, a mianowicie do kwestii genezy opisanego folkloru i literatury ludowej Karaimów litewskich. Otóż, Ananiasz Zajączkowski w swoich publikacjach wielokrotnie stawia tezę o pochodzeniu większości publikowanych i opisywanych tekstów (a w szczególności „Wróżb z drgań części ciała” i „Wykładania snów”), jak również opisywanych praktyk ludowych, z folkloru ludów turkijskich i także szerzej ludów muzułmańskich ${ }^{13}$. Przedstawia go jako rodzimy karaimski folklor pochodzenia turkijskiego, przyniesiony przez społeczność karaimską z Krymu, względnie zapożyczony z Krymu w okresie późniejszym.

Otwarcie archiwów Biblioteki Narodowej Rosji i dostępność rękopisów z kolekcji Firkowicza, dużego zbioru rękopisów karaimów polsko-litewskich zebranych przez Abrahama Firkowicza w trakcie jego pobytu na Litwie w latach

13 Por. np. A. Zajączkowski, Z dziejów literatury wróżbiarskiej, s. 32: „Zbyt bowiem frapujące jest podobieństwo tych wróżb, aby można było poddawać w wątpliwość ustalony przez nas pewnik, że wróżby krymsko-karaimskie powstały na podłożu i w środowisku kultury muzułmańskiej”; Tamże, s. 36: „Z tych przykładów wynika, że i tekst wróżb trocko-karaimskich należy uważać za filiację - choć dość odległą wróżb muzułmańskich, najbliżej spokrewnioną z wersjami tureckiemi segir-nāme, w szczególności zaś z sekirme-jorałary Karaimów krymskich.”; Zajączkowski 1938: 43: (odnośnie do „Wykładania snów”): Arabowie przypisują Danielowi wróżby z kresek i kropek na piasku (geomantyka), [...] oraz zasady wykładania snów [...]. Ten ostatni szczegół wskazuje jeszcze raz jak najwyraźniej, że źródła do wróżb karaimskich (o czym wspomniałem w poprzednim artykule o literaturze wróżbiarskiej) należy szukać właśnie w środowisku kulturalnym Wschodu Muzułmańskiego.”; tamże, s. 39 (odnośnie „Księgi Losów”, tj. „Sefer Goralot la-Achitofel”): „Jednak w tym wypadku wróżby muzułmańskie dostały się do kultury karaimskiej nie bezpośrednio przez piśmiennictwo tureckie, tak jak to widzieliśmy przy wróżbach z drgań, lecz za pośrednictwem wersji hebrajskiej. Na tym przykładzie łatwo możemy obserwować nawarstwianie różnych kultur, które oddziaływały na folklor karaimski.” 
1854-1856, rzuca jednak nowe światło na te tezy Ananiasza Zajączkowskiego. Po pierwsze, okazuje się że dwa wskazane utwory wydane krytycznie przez niego, tj. „Wróżby z drgań części ciała” i „Wykładanie snów”, są najpewniej przekładami utworów w języku hebrajskim, będących w posiadaniu społeczności karaimskiej na Litwie. Dokładne wersje hebrajskie tych utworów są zaświadczone w kilku hebrajskich karaimskich rękopisach z Litwy.

Utwór „Wróżby z drgań części ciała” znaleźć można m.in. w rękopisie z kolekcji Firkowicza Evr II a 146-1, 37 recto - 37 verso, skopiowanym przez Szemuela Esznabi, syna Awrahama, z Poswola lub Nowego Miasta, w roku 1669. Znany jest także z karaimskiego rękopisu Heb 8.3652 (fol. fol. 61 recto - 64 recto) z Trok z roku 1873, skopiowanego przez Jehudę Bezekowicza. Rękopis ten znajduje się obecnie w zbiorach Narodowej Biblioteki Izraela. Jego kopista, Bezekowicz, był później hazzanem w Trokach i w Symferopolu ${ }^{14}$. Występuje również w litewskim rękopisie Abkowicz 3 z pierwszej połowy XIX w. Oto początkowy fragment utworu w dosłownym przekładzie z języka hebrajskiego (Abkowicz 3, fol. 265 recto, $1-265$ verso,12):

„Z pomocą tego, który wzmacnia ręce słabe, opiszę znaczenie drgania, które jest w każdej części ciała. O tym, o czym pouczają każdym ruchem i wyglądem. O ranie i złamaniu. Albo o powodzeniu mężczyzny. By móc osądzić to, co się wydarza. Przyszłe rzeczy, które mają przyjść od Pana Straszliwego. Zacznę od głowy. W której części ciała czujesz, w tej szukaj wyjaśnienia. Jeśli komuś głowa drga, będzie mieć zatarg z kimś. Jeśli komuś mózg w głowie drga, wyruszy gdzieś i powróci bezpiecznie. Jeśli komuś skóra na twarzy, dostąpi wysokiej godności. Jeśli komuś róg twarzy od strony prawej, dozna radości. Jeśli od strony lewej, znajdzie coś cennego. Jeśli prawe ucho, coś cennego znajdzie. Lewe, tak samo będzie. Jeśli koniuszek prawego ucha, dozna dobrego. Jeśli lewego, dozna czegoś dobrego. Jeśli komuś szyja, wywoła kłótnię. Jeśli komuś prawe oko, będzie mieć synów i twarz mu się odmieni. Lewe, dozna radości.

14 O Jehudzie Bezekowiczu wiadomo, że urodził się w Trokach w roku 1858. W roku 1901 został starszym hazzanem w Trokach. W latach 1902-1903 i 1904-1905 pełnił obowiązki chachama Trockiego Zarządu Duchownego. Wiadomo, że z końcem 1905 roku opuścił Troki i przybył do Symferopola, gdzie został starszym hazzanem. Prawdopodobnie hazzanem w Symferopolu był do roku 1907. Nie jest jasne, jakie dokładnie były jego losy potem. Abraham Kahana w notatce w jednym z rękopisów zakupionych od wdowy po Bezekowiczu pisze, że „zgolił brodę” i został księgowym w fabryce tytoniu w Kijowie, gdzie też niedługo potem zmarł, por. rękopis Narodowej Biblioteki Izraela Heb. 8.5204, folio 0 verso. Jehuda Bezekowicz byl, wspólnie z Izaakiem-Boazem Firkowiczem, wydawcą Tehillot Israel (Berdyczew 1909). 
Jeśli komuś skraj prawej powieki, usłyszy coś dobrego. Lewej, w sądzie zostanie uniewinniony. Jeśli powyżej prawego oka, będzie płakać z czyjegoś powodu. Lewego, tak samo się stanie. Jeśli poniżej prawego oka, wszystko, co zechce, zdoła uczynić. Lewego, bogactwo znajdzie. [...]”

W wymienionym rękopisie Bezekowicza znaleźć można również hebrajską wersję tekstu „Wykładania snów”. Również ten utwór jest dobrze znany w wersji hebrajskiej pod nazwą „Pitrone Halomot le-Daniel” („Wyjaśnienia snów Daniela”). Zaświadczony został w wielu rękopisach. Utwór ten udokumentowany został w języku hebrajskim (poza społecznością karaimską) w kilku wersjach, przy czym najstarsza mi znana pochodzi z XV w. Oryginalnie najprawdopodobniej napisany został $\mathrm{w}$ języku aramejskim ${ }^{15}$. Początkowy fragment tekstu w rękopisie Bezekowicza ${ }^{16} \mathrm{w}$ dokładnym polskim przekładzie brzmi następująco:

„To są wyjaśnienia snów, które ukazał Daniel, umiłowany mąż, w Babilonie, w dniach Nabuchodonozora. Ja Daniel, mieszkałem w Babilonie. Błagali mnie ludzie, bym dał im poznać wyjaśnienia snów, tak jak pokazał mi Pan, niech będzie błogosławiony. Niczego nie dodałem i nie ująłem niczego. Jeśli ktoś widzi sen w szabat lub w wieczór po szabacie - [ten sen] sprawdzi się. Albo w niedzielę. O ile nie zaśnie po nim. Jeśli ktoś widzi owce we śnie albo koźlęta - [jest to zapowiedź] czegoś dobrego dla niego. Jeśli ktoś widzi siebie samego, gdy jest w zielonym, we śnie - [zapowiedź, że] zostanie zniesławiony. Jeśli ktoś widzi srebro i złoto - jest to zapowiedź zysku.”

Przekład Zajączkowskiego odnośnego fragmentu z języka karaimskiego brzmi następująco:

„Ja, Daniel, przebywałem w Babilonie, a lud błagał [...] mnie, aby ujawnić im z n a c z e n i a s n ó w, tak jak pokazał to mi Bóg [...] - oby głoszono Jego chwałę! Nie dodałem nic (do tych objaśnień), ani też nic nie usunąłem z nich. A oto pierwsze:

1. Kto widzi (coś) we śnie w sobotę, to jest trwałe (sprawdza się), tak samo w pierwszym dniu (tygodnia, w niedzielę), jeżeli (ten człowiek) nie zaśnie potem.

Kto widzi we śnie j a g n i ę t a albo k o z y, dobrze mu się będzie działo.

15 Por. P. Muchowski, Folk Literature of the Polish-Lithuanian Karaites: Abkowicz 3 Manuscript, Part 2, Paris 2013, s. 113-114, przypis 293.

16 Por. Heb 8.3652, folio 64 recto -64 verso. 
2. Kto we śnie ujrzy siebie samego w z i e l e n i (zielonym kolorze), zła opinia (plotka) ujawni się o nim.

Kto widzi we śnie s r e b r o i zło t o - przepowiednia to osiągnięcia korzyści."17

W przypadku pozostałych utworów opisywanych przez Ananiasza Zajączkowskiego, przynajmniej niektóre wydają się z pewnością być przekładami z hebrajskiego. Cytowana przez Zajączkowskiego „Księga Losów”, co do której odnotowuje, że weszła do ludowej literatury karaimskiej za pośrednictwem języka hebrajskiego, zachowała się w hebrajskiej wersji w zbiorze rękopisów Firkowicza. Możemy ją znaleźć, pod hebrajskim tytułem „Sefer Goralot la-Achitofel”, między innymi w rękopisie Narodowej Biblioteki Rosji Evr I 264. Tekst utworu dokładnie odpowiada temu cytowanemu przez Zajączkowskiego w polskim przekładzie z karaimskiego. Niewątpliwie mamy do czynienia z tą samą wersją tekstową utworu ${ }^{18}$. Początkowy fragment Evr I 264 w przekładzie $\mathrm{z}$ hebrajskiego brzmi następująco:

„To jest Księga losów. Sporządził ją Achitofel z Gilo. Jest to wielka tajemnica, jak dowiedzieć się bez losów, bez wyliczania, bez trudu i bez wysiłku. Jest w niej coś, co niezmiernie zadziwia. Jeśli przyjdzie człowiek i zapyta cię o jakąkolwiek rzecz, o którą będzie chciał zapytać, powiesz mu. Pomyślisz w swym sercu, zgodnie ze swą wiedzą, twoje pytanie, a potem sięgniesz ręką do jednej z tych dziewięćdziesięciu strof, w których są litery napisane od 1 do 90. Ta liczba, którą weźmie, pójdzie i poprosi w swej strofie. I oznajmi ci odpowiedź na to, o co on prosi, czy spełniona zostanie jego prośba, czy nie [...]”19.

Na folio 27 verso zamieszczony został kolofon potwierdzający, że rękopis był własnością Karaimów litewskich. Czytamy w nim:

„Tę Księgę losów spisałem ja, dla siebie, dla pamięci, gdy zobaczyłem piękno prośby, która jest w niej. Nie po to by, się nią posłużyć - broń Boże, bym uczynił coś takiego, ale by postępować zgodnie z tym, co zostało zapisane w niej. A On, niech będzie błogosławiony, niech spełni szczęśliwie wszystkie moje prośby. Takie są słowa piszącego, Szemuela Esznabi, syna mojego pana, ojca

\footnotetext{
$17 \quad$ A. Zajączkowski, Teksty i studia..., s. 46.

18 Por. Zajączkowski, Z dziejów literatury wróżbiarskiej, s. 37.

19 Folio 21 recto.
} 
i nauczyciela, Jego Mości Pana Awraha[ma], błogosławionej pamięci. Zapisane zostało w poniedziałek, 8 szewat, roku 431 wedle skróconej rachuby ${ }^{20}$."

Można przypuszczać, że również niektóre cytowane utwory zielarskie i lecznicze są przekładami z hebrajskiego. Świadczy o tym hebrajski termin refu'a, czyli „lekarstwo”, którymi są wprowadzane ${ }^{21}$. Utwory takie, znane pod hebrajską nazwą refu'ot są licznie zachowane w różnych rękopisach hebrajskich. Znaleźć je można między innymi w rękopisie Abkowicz 3. Nawet wzmiankowana przez Zajączkowskiego formuła magiczna na ujawnienie złodzieja znana jest - choć nie wiadomo, czy w tej samej wersji tekstowej (Zajączkowski nie podaje jej brzmienia $)^{22}-\mathrm{z}$ karaimskich rękopisów litewskich w języku hebrajskim. Zaświadczona została w Bet Awraham, rękopisie lekarza trockiego Awrahama ben Joszijjahu, z XVII w. (por. Instytut Rękopisów Orientalnych, B 263, fol. 79 recto) oraz w rękopisie Abkowicz 3, fol. 279 recto. W rękopisie Abkowicz 3 występuje nadto przynajmniej kilka tekstów typu hemerologion, podobnych do tych cytowanych przez Zajączkowskiego ${ }^{23}$. Tego rodzaju utwory były popularne w literaturze z zakresu kabały praktycznej. Oczywiście, z pewnością nie wszystkie opisywane teksty literatury ludowej musiały być przekładami z językami hebrajskiego. Niewątpliwie część z nich pochodzić mogła z folkloru ludów słowiańskich, a także z krymskiego folkloru turkijskiego. W przypadku zbioru podobnych tekstów w rękopisie Abkowicz 3 udało się ustalić, że niektóre z nich zaczerpnięte zostały z polskiej literatury ludowej i przełożone przez Karaimów litewskich w XVIII i XIX w. na język hebrajski.

Na podstawie różnych danych można przyjąć, że literatura tego typu, na którą składały się głównie teksty o charakterze leczniczym i wróżbiarskim, rozpowszechniła się w społeczności karaimskiej na Litwie w XVII w. pod wpływem niezwykle popularnej wtedy kabały luriańskiej. Jesteśmy obecnie w stanie ustalić imiona niektórych karaimskich uczonych, odpowiedzialnych za przenikanie i upowszechnianie utworów kabalistycznych. Są to m.in. Ezra Lekarz, syn Nisana (Ezra ha-Rofe ben Nisan, 1595-1666), Abraham Jozyiaszewicz (Awraham ha-Rofe ben Joszijjahu; 1636-1687), Szełomo, syn Aarona (Szelomo ben Aharon, zm. 1745) ${ }^{24}$. Sima Izaak (Simcha Icchak) Łucki pisze wręcz o powszechności tego zjawiska:

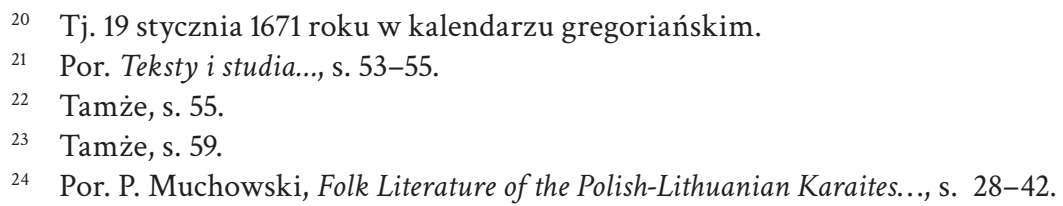


„[...] i tak wielu z uczonych karaimskich, którzy mieszkali w gminach okręgów litewskich, dobrze wykształciło się i miało dokonania w nauce kabalistycznej. Byli bardzo wybitni w jej (odmianie) teoretycznej i praktycznej, jak na przykład (nasz) wielki (nauczyciel) ribbi Jehuda, syn Jego Mości Pana Aarona, który to udawszy się do świętej gminy konstantynopolskiej, nauczył się tam nauki kabalistycznej u jednego z uczonych rabbanitów. Gdy wrócił do świętej gminy Troki, uczył niektórych wybranych, jak na przykład wspaniałego uczonego i filozofa, znakomitego, wybitnego w obu naukach, naszego wielkiego nauczyciela ribbi Awrahama Lekarza, niech spoczywa w raju, syna (naszego) wielkiego (nauczyciela) ribbi Joszijjahu [...”25.

Wydaje się, że ta literatura kopiowana i rozpowszechniana przez niektórych karaimskich uczonych z inklinacjami do mistycyzmu i kabały luriańskiej stała się w kolejnych wiekach integralną częścią karaimskiej literatury ludowej na Litwie.

Podkreślić oczywiście należy, że wedle zasad judaizmu karaimskiego utwory takie i związane z nimi praktyki były zakazane. Na podstawie przykazań Tory są one wskazywane w Adderet Elijjahu i innych karaimskich tekstach doktrynalnych jako bałwochwalcze i niedozwolone ${ }^{26}$. O tym, że literatura tego typu (i związane z nią praktyki) była nieoficjalnie popularna w społeczności karaimskiej na Litwie już od przynajmniej XVII w., świadczą m.in. dwie zachowane uchwały kongresów (sejmików) karaimskich z 1665 i 1776 r., skierowane wyraźnie przeciw praktykom wróżbiarskim. Uchwały te mają w obu przypadkach tę samą treść: „Nie powinni zwracać się do wróżbitów i wyroczni, a ten kto miałby czelność (winien ponieść) wielką karę"27.

Opublikowane przez profesora Zajączkowskiego teksty, przynajmniej w części, są niewątpliwie karaimskimi przekładami tekstów należących do gatunku kabały praktycznej. Zgodzić się przy tym należy z profesorem Zajączkowskim,

25 Por. Sefer Liwnat ha-Sappir, Instytut Rękopisów Orientalnych, B 307, fol. 8 verso (w nowej numeracji 7 verso).

26 Zob. np. Aharon ben Elijjahu z Nikomedii, Sefer Keter Tora, Komentarz do Księgi Wyjścia (w wydaniu z Gözleve 1867 fol. 21 verso); Jehuda Hadassi, Sefer Eszkol hak-Kofer, rozdz. 103 (w wydaniu z Gözleve 1836 fol. 43 recto); Elijjahu Basziaczi, Sefer ham-Micwot han-Niqra Adderet Elijjahu, Injan Awoda Zara (Sprawa Bałwochwalstwa), rozdz. 2 (edycja z Gözleve 1834: fol. 52 recto). Zakaz tych praktyk, określanych mianem „bałwochwalstwa” lub „dziewięciu obrzydliwości”, wywodzony był z Księgi Powtórzonego Prawa 18,10-11 oraz Księgi Kapłańskiej 19,28.

27 Zob. J. Mann, Texts and Studies in Jewish History and Literature. Vol. 2: Karaitica. New York 1972, s. 831 (Uchwały kongresu w 1665 r.), s. 964 (Uchwały kongresu w 1776 r.). 
że teksty te w dużej części wywodzą się oryginalnie z Bliskiego Wschodu, funkcjonowały w wielu wersjach językowych i stały się wspólnym dziedzictwem kultury ludowej wielu ludów. Niemniej - jak dowodzą zachowane dane - do społeczności karaimskiej przenikały głównie w wersji hebrajskiej, za pośrednictwem kabalistów litewskich i, jak wskazuje przekaz Simchy Łuckiego, również kabalistów z Konstantynopola ${ }^{28}$.

28 Por. P. Muchowski, Folk Literature of the Polish-Lithuanian Karaites..., s. 38-41. 